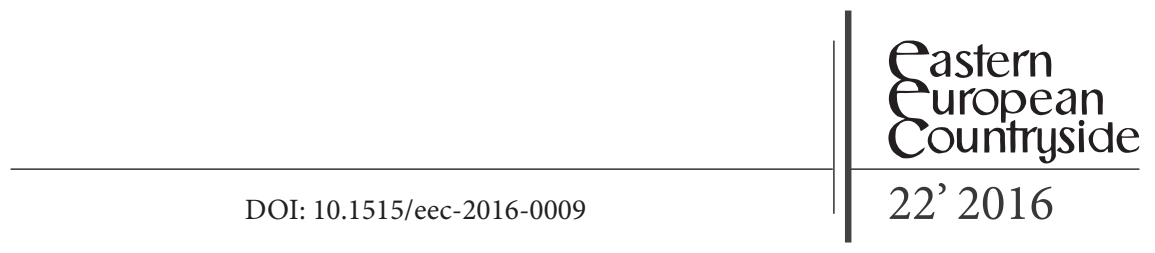

Ioan Sebastian Jucu

Department of Geography, West University of Timişoara, Romania

\title{
From State-Socialist Ambitions of Romanian Rural Indutrialisation to Post-Socialist Rural Deindutrialisation: Two Case Studies From Romania ${ }^{1}$
}

\begin{abstract}
The post-socialist changes in Romania's communities profoundly changed the rural settlements with similar, contrasting and tensioned trends in the local rural development. The purpose of this study is to focus on the post-socialist rural dereliction. The paper unveils the post-socialist rural transformation in Romania, from the state-socialist interventions in rural industrialisation, to the post-socialist rural identity formation, using both quantitative and qualitative methods. During this process, two sampled case studies were thoroughly analysed, namely the Tomești and Margina communes - two rural settlements intensely industrialised under the former state-socialist political regime and with multiple consequences during the post-90s period in their local development. According to recent theories on economic changes reflected in local rural spatial development,
\end{abstract}

1 This work was supported by the Strategic Grant POSDRU/159/1.5/S/133391, Project "Doctoral and Post-doctoral programs of excellence for highly qualified human resources training for research in the field of Life Sciences, Environment and Earth Science". It was co-financed by the European Social Fund within the Sectorial Operational Program Human Resources Development 2007-2013. 
the idea of rural dereliction remains peripheral and, at the same time, a hot-spot issue in the contemporary research on rural restructuring. In addition, recent theories on social and economic changes provide useful frameworks in studying the production of rural ruins. With post-socialist deindustrialisation, and under new post-90 capitalist rules in local rural development, rural communities faced multiple problems in creating their own post-socialist identity. Accordingly, this study highlights the local problems of rural deindustrialisation in the inner rural pattern of the investigated sites. While some rural communities embrace slow rural spatial regeneration trends, others remain ruined, marginalised and declined. The findings of the study confirm the presence of derelict abandoned places, thus highlighting the need for further proper interventions in local rural development, and for further fertile scientific dialogues to promote suitable strategies in Romanian rural regeneration on the local scale.

Keywords: industrialisation, deindustrialisation, rural space, dereliction, Margina, Tomești, Romania

\section{Introduction}

During Eastern Europe's post-90s period, a whole body of specialised literature focussed on the post-socialist economic changes of Eastern European communities, thus fueling the interest of worldwide scholars. Their analyses mostly approached the post-socialist urban identity formation on different socio-spatial scales: local, regional, national and international (see Stanilov 2007; Kideckel 2008). Furthermore, difficult backgrounds of post-socialist transition with uneven spatial benefits were the driving forces behind the social and economic disparities (Čikić and Petrović 2015) of rural areas. Against such a background, the rural sites remained marginalised (Cloke, Crang and Goodwin 2014) and occupied a second-tier position in the current scientific debates concerning the post-socialist social and economic transformation. Moreover, research remains mainly under-developed in peripheral rural municipalities (see Bečicova and Blažek 2015). A wide range of studies have unveiled multiple transformations in rural communities, with their topics focussing on various issues of the post-communist transitional economy in rural space (O’Brien, Españo, Grigsby and Patsiorkovsky 2011). Indeed, these transformations sparked interest among various scholars, particularly 
the processes of reshaping rural areas, rural poverty and uneven development, as well as rural social changes related to the government decisions, local initiatives and the politics in countryside areas (Kovács 2010; Majerova 2009; Artemov and Novokhatskaya 2014; Lukić, Penjišević, Đerčan, Đurđev, Živković and Armenski 2014). In addition, employment policies, the rural labour market (Kerekes and Pakucs 2013; Róbert and Levente 2014) and local rural development (Manea, Matei, Vijulie, Marin, Cocos and Tiscovschi 2013; Gorlach, Klekotko and Nowak 2014) were topical problems of rural areas. Indeed, these were rigorously investigated in line with the post-90s market economy transition.

Considering social and economic transformations in rural areas under the present umbrella of global policies, reflections on the inner-rural spatial shifts and rural change (see Cloke, Crang and Goodwin 2014) launched multiple studies focussed on local rural development. In this regard, leadership interventions as a key action in local countryside formation (Esparcia, Escribano and Serrano 2015) provided new visions in the present rural development. Of these interventions, the capitalisation of local agritourism potential (see Srisomyong and Meyer 2015) sustaining the local and regional cultural identities of rural areas (see Preda, Vijulie, Manea and Mareci 2015) would turn the countryside communities into new arenas for social and economic development. Nevertheless, in Eastern European Countries, rural areas still face important negative outcomes in their transition from former state-socialist policies to a capitalist social and economic background. Depopulation, out-migration, and low living standards are only a few of the processes fueled by the post-socialist transitional policies and economies. Among different studies topically framing the post-socialist backgrounds of social and economic changes, deindustrialisation and its related consequences remain, however, peripheral, as the rurality stands in the present contested cultures (see Cloke and Little 1997). Consequently, in terms of the spatial consequences of urban deindustrialisation, issues related to the rural space transformation of Central and Eastern European Countries raise important challenges in the present research. Of these, multiple issues translate to Romanian rural areas, with particular socio-economic and spatial results in the inner-rural patterns of Romanian countryside.

The Romanian state-socialist industrialisation was followed by postsocialist deindustrialisation, which traced the rural areas. Indeed, dereliction is an important feature that must be considered. Regardless of whether 
it was under state-socialist times, agriculture was the key sector of the rural economy (Baum 2011). The former state-socialist Romanian government ruled, on different scales, intensive policies in rural industrialisation. Consequently, the processes of rural restructuring, rural deindustrialisation and countryside industrial ruins remain peripheral in the current scientific debates. Indeed, the local identities which people use to identify themselves (Bucher and Nováková 2015) represent a certain post-socialist scene for critical investigation on rural restructuring. Long-term rural change through the lens of statistical data, spatial rural restructuring and the outcomes of manufacturing decline, has been a key feature of recent rural spatial shifts. Hedlund and Lundholm (2015) considered assessing the spatial results of post-socialist transition associated with the global economic changes that shifted the contemporary human settlements (see Paddison and Hutton 2015). This paper aims to assess the post-socialist rural formation, and consider the importance of the Romanian rural habitats. Indeed, Romania is still, to a large extent, rural $-46.11 \%$ of its national population are living in rural areas (NIS 2013). As such, this paper draws on a peculiar topic related to the post-socialist changes and industrial dereliction in rural places. In an attempt 'to make our geographies of the rural more open', as suggested by Cloke (Cloke 2014: 736), this study is concerned with the local shifts occurring during transition from the former state-socialist economy to the post-90 rules of new capitalism in reshaping, reframing, ordering and disordering the Romanian rural communities. Specifically, this study is concerned with the outcomes of rural deindustrialisation and its factual results in the local spatial rural patterns, as well as in the local ways of life for rural inhabitants. What led to the former state socialist industrialisation? How did rural people live with the communist industry? Why did deindustrialisation appear and how did it alter the rural communities? What claimed the voices of local residents? How did post-socialist policies in rural (re)development alter the local rural culture? These are the questions of the present study. In order to investigate these issues, the article proceeds as follows. First, a theoretical section launches the conceptual field of the study, theorising the issues related to this investigation. Second, the study area, data and methods frame the methodological design and area of investigation. Third, the findings section reveals the main issues related to the post-90s rural socio-spatial changes in the villages of Margina and Tomeşti, from the state-socialist ambitions of rural industrialisation, to the post-socialist deindustrialisation. 
Indeed, their results in the local rural communities are translated into local ruins and into the local way of life for the rural population.

\section{Theoretical background}

Post-socialist rural identity formation is a complex process arising from the numerous political, economic, social and cultural transformations that occurred during the post-90s period in Romania. This country, as with all Eastern European block countries, encountered important changes in local communities (Stanilov 2007; Kiss 2007). Indeed, 25 years after the statesocialism breakdown, the Romanian rural identity is still in progress, due to the political and economic incoherence at the national level (see Chelcea 2012). Furthermore, the major changes in the national economy marked out the rural communities of Romania.

From the former state-socialist industrialisation, to the post-90s deindustrialisation, Romanian countryside, as with other formerly communist countries, encountered important difficulties, radical changes and socialeconomic transformations in reframing its local identity (see Jakimovski 2010; Măjerová 2009). With regard to artificial programmes of national statesocialist industrialisation (Rey, Groza, Ianoş and Pătroescu 2005) designed in local development of the villages, the rural space lost its identity, with many villages and communes artificially turned to urban places. This trend continued after 1990 against the background of the post-socialist transition to a market economy and economic globalisation, with multiple consequences for post-90 Romanian rurality. Between these old and new interventions, Romanian countryside still fought for its recognition and for its own identity, with Romania itself remaining, to a large extent, rural (see Arunas and Arunas 2010); indeed, more than $40 \%$ of the total population is rural (Table 1). In actual fact, industrialisation was argued as a process of industrial growth, increasing the factory system and the manufacturing industries in 'countries or regions where people are engaged mainly in agricultural activities' (Clark 1998: 201). This was the case for Romanian rural settlements that encountered significant transformation under the former state-socialist system, closely related to the former state-socialist forms of industrial production and to their associated policies of industrial diffusion to rural areas (Groza, Ianoş and Pătroescu 2005; Ianoş 2005; Şandru and Aur 2009). These artificial 
interventions in rural areas have been demonstrated by the post-socialist rural evolution which has taken place since the beginning of the transition.

Under the post-socialist umbrella of new capitalism and economic globalisation, when the benefits of transition had been unequally distributed (Čikić and Petrović 2015), deindustrialisation as 'one of the most striking features of the transition to advanced capitalism' rapidly appeared with a 'sustained decline in industrial, especially manufacturing, activity' (Pacione 2009, p. 302, 676; see also Norton 2004). It was characterised by important employment losses in local manufacturing and in its related economic activities (Kaplan, Wheeler and Holloway 2009, p. 93). Deindustrialisation had a negative impact on local communities, which manifested itself in the form of out migration, unemployment (Pacione 2009) and other social and economic costs in local development. Furthermore, the process appears as a 'loss of manufacturing activity and related employment in a traditional manufacturing region' (Norton 2004). The decline of manufacturing production was also a key force in the contemporary rural change (Hedlund and Lundholm 2015) with deindustrialisation being 'a major challenge for the new independent states' (Pacione 2009, p. 111). Against such a theoretical backdrop, Romania fit with these changes, its deindustrialisation complying with the strong failure of state-socialist industrial production and with the bankruptcy of the former state-socialist industrial manufacturers. In light of this, the factories closed down (Ianoş 2005) because of bad privatisation and mismanagement under the new market economy umbrella (Kideckel 2008). Besides this, many important industrial plants turned to ruins and derelict areas, harming both urban and rural communities (see Edensor 2005; DeSilvey and Edensor 2013; Mah 2012; Voiculescu and Jucu 2014; Chelcea 2008; 2015; Jucu 2015), and threatening their cultural traditions with damages to local residents' way of life. These issues are thoroughly analysed in the following sections.

\section{Study area, data, materials and methodological flow}

Romania is an Eastern European Country that embarked on an important transformation under post-socialism, both in urban and rural areas. Of these, two peculiar countryside communities were sampled in the present study, since ethnographic case-studies remain important in rural studies (McKee 2015) 
when it comes to portraying the results of post-90s rural deindustrialisation. The cases studies were the Tomessti and Margina communes, both of which are situated on the eastern outskirts of Timiş County (Figure 1). The first countryside settlement was an important traditional hub of the glass industry, while the second development was related to vinegar production, specifically a factory connected to a large petrochemical plant in Timişoara (the capital of Timiş County). During post-socialist deindustrialisation, the latter went bust, experienced bankruptcy, and fell into ruin (see Voiculescu and Jucu 2014) as was the case with the aforementioned factories from Margina and Tomeşti. Consequently, spaces of dereliction appeared, with their ruins giving rise to a negative impact of economic Romanian transition to a market economy. To analyse this issue, a multi-method approach was used throughout (conducted from January to June 2015) with the investigated sites repeatedly visited.

Figure 1. Study area: geographical location of sampled case studies: Tomeşti and Margina communes from Timiş County of Romania

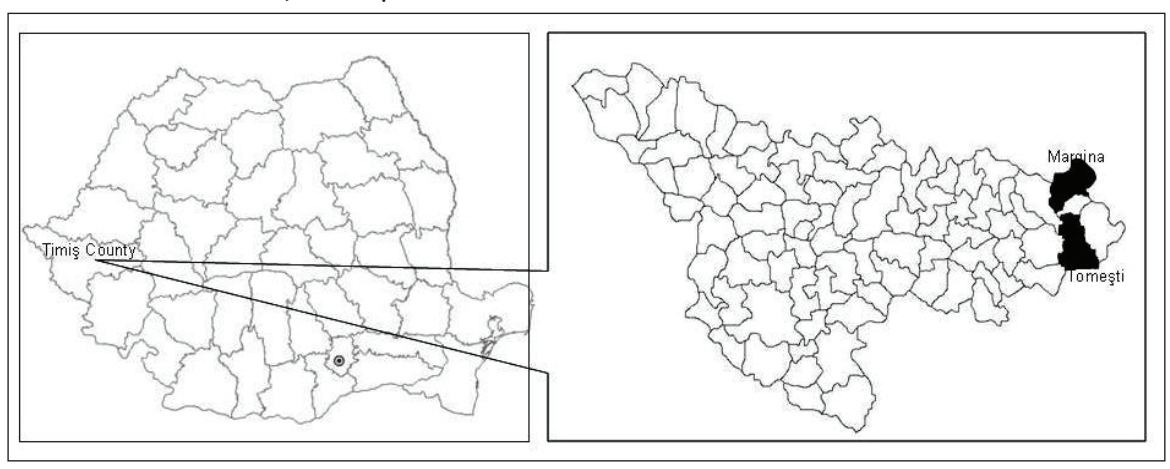

Source: author's own working.

Indeed, field and ethnographic observations were helpful in gaining an understanding of the most important post-socialist changes in local economies and in the local residents' way of life. In order to assess the social and economic transformation, as well as the social and economic costs of local deindustrialisation, the local official statistical data provided by the National Institute of Statistics, Romania (NIS 2013, Romania) were helpful in analysing these economic changes. Consequently, reference was made to local rural changes analysis through longitudinal statistical data (Hedlund 
and Lundholm 2015) related to investigated sites, which had been available since 1990 through to 2014. Indeed, these data were helpful in highlighting the Romanian rural post-socialist changes framed by rigorously studied ethnographic case studies (McKee 2015). These primary statistical data were completed with qualitative research. In doing so, a 'random sample of inhabitants who live in the countryside' (Lukic, Penjišević, Đerčan, Đurđev, Živković and Armenski 2014, p. 100) was used for discussion and personal conversations focussed on these post-socialist changes. Approximately 100 personal conversations were conducted with local residents in order to identify the issues affecting their daily life under the post-socialist umbrella of local deindustrialisation. Attempting to triangulate the major findings, we analysed the local monographs, as well as the key literature focussed on local rural deindustrialisation and available information from media. In this regard, articles from local and regional newspapers, and from official websites, were useful in gaining an understanding of the countryside changes from the state-socialist ambitions of rural industrialisation to a post-90s social and economic background in the sampled case studies. The next sections unveil these changes, portraying the social and economic costs of the local communities of Tomeşti and Margina.

\section{Findings and results}

\section{From state-socialist ambitions of rural industrialisation to post-socialist industrial decline}

As previously stated, since the end of the Second World War, Romania has been an agrarian country in Europe. Despite this economic status, Romania was an important European state providing agricultural goods throughout Europe. During these times, Romanian industrialisation was limited, and this would eventually turn into an extreme process (Rey, Groza, Ianoş and Pătroescu 2005) both in urban and rural areas. It started in 1962, with Romania refusing to obey CAER and be agrarian (Rey, Groza, Ianoş and Pătroescu 2005). Consequently, a large programme and huge interventions in national industrialisation started, translating the employment in agriculture to the industrial sector. Against such a backdrop, the rural functionalities and landscapes changed, reframing the local way of life of the rural population. 
Large industrial plants and related facilities appeared in Romanian rural space, producing industrial rural sites.

This stage continued up to 1990, when Romania turned from a statesocialist centralised industrial country, to a new democratic nation governed by transition to a post-socialist political system oriented to the market economy and to the capitalist regulation on national economy. These 25 years of post-socialism produced important changes in the domestic economy, with major consequences at the national, regional and local level. Among others, the main outcome was deindustrialisation and its related results in the Romanian demographic capital, in the employment sector, and in the local rural ways of life. A decreasing rural population, high unemployment rates in rural areas, insecure low incomes and drastic decline in living standards due to transition (Jakimovski 2010) were important outcomes of the new post-90s social and economic regulations in post-socialist Romania.

In addition, rural depopulation remained an important feature for all rural Romanian sites, as was the case for all of the Eastern and Central European Countries (see Čikić and Petrović 2015). These translated from national to local levels of rural communities. The aforementioned issues fit with the analysed rural communities sampled for this study: Tomeşti and Margina. Since 1992, these communes have encountered a continuous decreasing trend (Table 1) of total population (Figure 2). The same was true for total employees in investigated areas. From 1890 employees in 1992, the communes of Tomeşti and Margina registered 679 employees in 2014, with most of them hired in services and agriculture (Figure 3). Since the local rural industrial activities failed, the workers in industry were mainly employed in the closest towns of Lugoj and Făget, and in small private mills in Tomeşti and Margina. 
Table 1. Some basic data on demographic statistics* in Romania, Timiş County, Tomeşti and Margina Communes

\begin{tabular}{|l|r|r|r|r|r|}
\hline \multicolumn{1}{|c|}{ Year } & \multicolumn{1}{c|}{1992} & \multicolumn{1}{c|}{2000} & 2005 & 2010 & 2014 \\
\hline Total population, Romania & 23143860 & 22825288 & 22648514 & 22516004 & 22346178 \\
\hline Urban population, Romania & 12478618 & 12571927 & 12815627 & 12765553 & 12622553 \\
\hline Rural population, Romania & 10665242 & 10253361 & 9832887 & 9750451 & 9723620 \\
\hline Total population, Timiş County & 707623 & 709852 & 712359 & 727041 & 737881 \\
\hline Urban population, Timiş County & 430675 & 438564 & 457249 & 457365 & 455211 \\
\hline Rural population, Timiş County & 276948 & 271287 & 255110 & 269676 & 282670 \\
\hline Total population in studied areas & 5323 & 5022 & 4858 & 4677 & 4429 \\
\hline Tomeşti Commune & 2876 & 2660 & 2472 & 2286 & 2132 \\
\hline Margina Commune & 2447 & 2362 & 2386 & 2391 & 2297 \\
\hline Year & 1991 & 2000 & 2005 & 2010 & 2013 \\
\hline Employees in studied areas, total & 1890 & 632 & 554 & 598 & 679 \\
\hline Tomeşti Commune & 1278 & 155 & 207 & 291 & 357 \\
\hline Margina Commune & 612 & 342 & 307 & 322 \\
\hline
\end{tabular}

Source: NIS Romania, 2014; The City Halls official websites. ${ }^{\star}$ At the level of national and regional statistics this is considered the permanent resident population.

Figure 2. Decreasing trends of the local residents during post-socialist period in Margina and Tomeşti

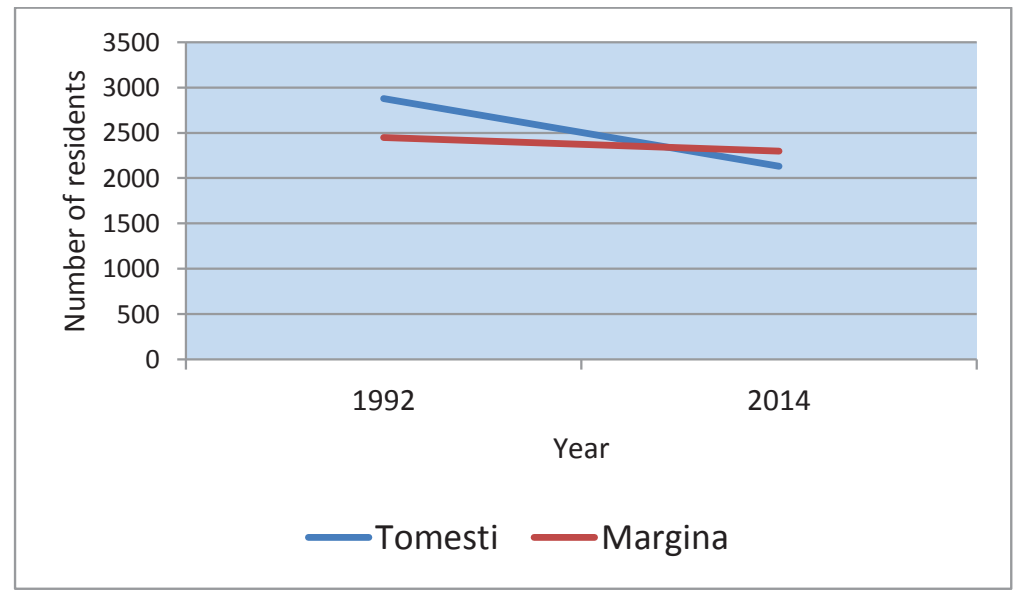

Source: own research. 
Figure 3. Decreasing trends of the total number of employees in Margina and Tomești

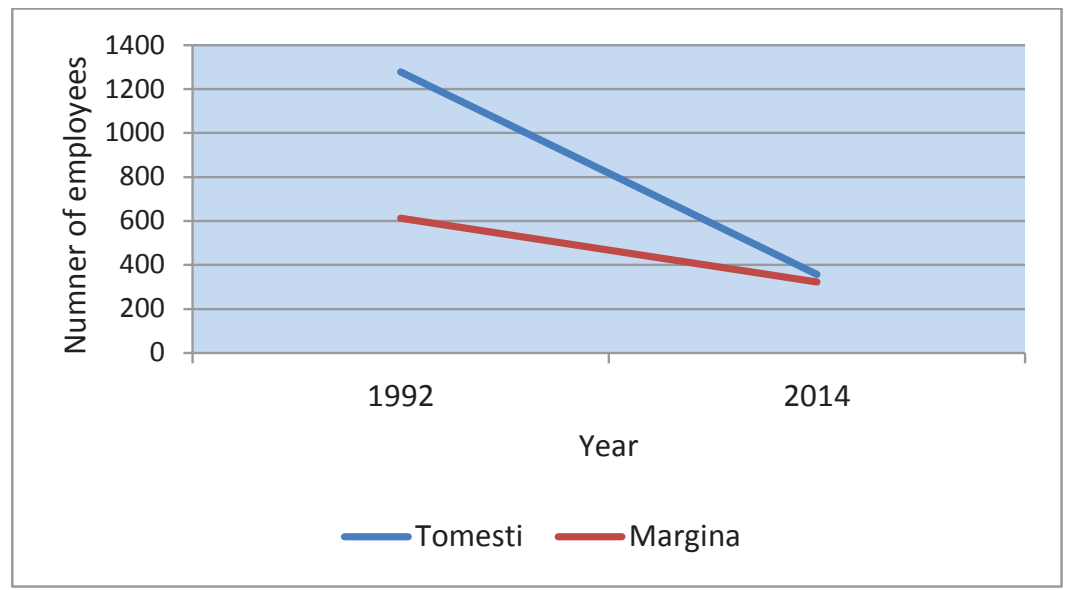

Source: own research.

Local colonies are mainly responsible for both the state-socialist development of the rural spaces and for the post-socialist economic decline in rural areas. The colony is an old and new concept when it comes to the spatial expansion of Romanian settlements. The first sense was given to the historic colonisation with the German and Hungarian population in the $18^{\text {th }}$ Century in Banat and in western Romania (Crețan 2006; Voiculescu 2004). Possibly inspired by this model, the former statesocialist regime designed important colonies once industrialisation had been implemented in Romania. These colonies appeared both in urban and rural settlements with the same ambition: to develop the Romanian economy based on industrial activities (see also Jucu 2011). Consequently, important colonies with workers shaped urban and rural Romanian settlements. These often comprised blocks of flats - standardised dwellings with low housing facilities - for workers. The colonies were built up in vacant lands or were constructed using previously built areas with individual houses that were further demolished. In view of this issue, it is considered that the former state-socialist regime would try to turn the rural areas into urban sites using industry as a tool for local development. However, these interventions were artificial and brutal, altering the local way of life of rural residents. Many households were demolished and rural residents were forced to move out of their houses 
to new collective and often improper houses. Thus, important local rural traditions were lost and the rural landscapes were reshaped, with industry becoming a new factor in rural development. This rural hybridisation would dramatically change the Romanian countryside, both under statesocialism rules and during the post-socialist transition. The next sections unveil these major implications in the rural communities of Tomeşti and Margina, with rigorous analysis unveiling the outcomes of post-socialist deindustrialisation under the new market economy.

\section{Tomeşti countryside between decline and frail rural regeneration}

The first investigated site is the commune of Tomeşti, 2 kilometres from which is the colony of Tomeşti (Figure 4), a separate settlement with its destiny closely related to the appearance of the Glass factory, built 189 years ago. It was the starting point of this area's industrial tradition, and would go on to become an important factor in the local rural industrialisation.

Figure 4. The marks of Tomeşti Colony at the entrance and the exit to the rural settlement

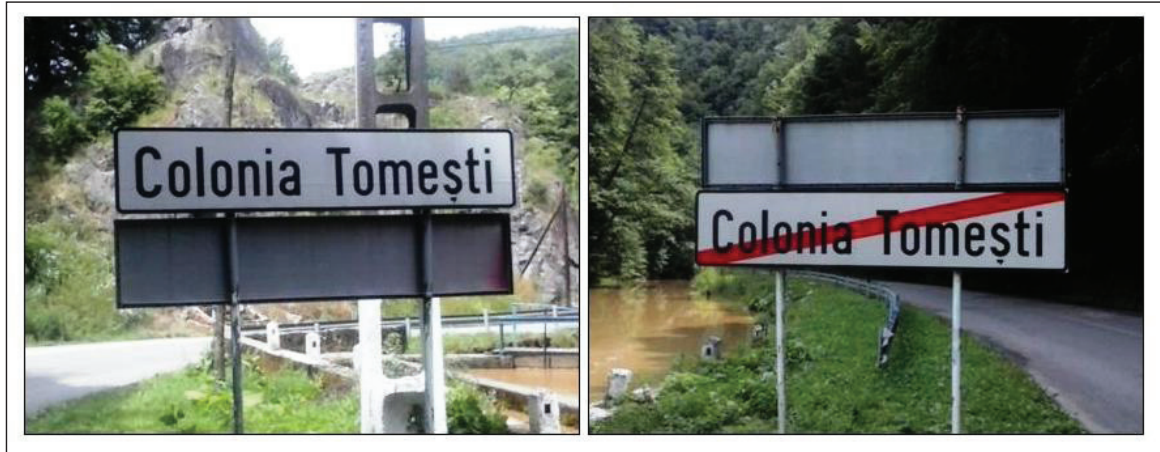

Source: photographs taken by author, 2015.

The first glass manufacturer appeared in 1826 under the capitalist economic order of the former Austro-Hungarian Empire, with its functionality based on the local resources, especially wood (used for the furnace heating), quartz and quartz sand (used in the production of glass and lime resources). The local water resources were also useful in the production processes of the factory. The close connection of local resources and production had an important role to play in the functioning of the whole empire. Most of the 
workers hired were Germans, especially at the beginning of the factory's life $^{2}$. Later on, and by German workers, the labour force was recruited from surrounding rural areas. As of 1846, the factory was under the ownership of Austrian manufacturers and a large process of workers' training started. Against such a backdrop, the goods achieved important success in the market, being sold all through the empire. At the beginning of the $20^{\text {th }}$ Century, the factory expanded, operating in 1918 with 120 employees working 16-18 hours per day. Between 1922 and 1928, new major investments were made in the factory's development; indeed, in 1929, before the economic crisis, the production of the plant was estimated at 40 million Lei. It was a huge profit for that time. In addition, new houses and dwellings appeared in the colony of Tomeşti and the local community continued to develop. An important point in the progress of the colony was the construction of the local railway, ensuring wood transportation to and from the glass factory. The crises of 1929-1933 contributed to the profit decreases, but the factory operated with employees working without salaries. The earlier capitalist stage marked the factory's production due to the market competition. Consequently, it was repeatedly closed between 1931 and 1937. An important moment in the history of the glass plant was the year of 1948, when the nationalisation ruled by the new state-socialist regime was implemented. At those times, the factory under the state ownership operated with 200 workers, an important number of employees for those times in rural areas. In 1956, a new railway connecting Tomești and Margina opened. It was used for raw materials, goods and the transportation of workers. Furthermore, this railway linked the communes of Tomeşti and Margina, diffusing industrial development to the latter rural site. The glass factory continued to develop, hiring 1500 employees in 1979. It was an important number of workers in industry in this rural community, highlighting the former state-socialist ambitions of industrialisation of the Romanian rural communities. Because of the national policies in Romanian rural industrialisation, the factory expanded its area between 1975 and 1980,

2 This short history of Glass Factory and the local ways of life of those times based on the local monographs research (see Ceauşescu and Ceauşescu (2004a, 2004b, 2006a, 2006b) and other references such as Mihalache and Nini (1971), Bradea et al. (1981), Munteanu and Munteanu (1998), Ghinea (2000), and Ghinea and Ghinea (2000). With regard to this information, the following websites were useful in gaining important accounts of the history of the local community of Tomeşti:http://www.tomesti.ro/monografia-comunei and www. tomesti.ro. Online accessed June-July, 2015. 
becoming one of the most important glass producers, with old tradition strongly embedded in the earlier capitalist stage (Ceaușescu and Ceaușescu 2006a). The year of 1985 brought a world first, when two researchers invented phosphate polymetallic glass. According to Law No. 15 and Law No. 31 and to the Government Decision No. 1254/1990, the glass factory became SC. Stitiom SA, with 1127 workers employed and approximately $40 \%$ of its production exported all-through Europe. Since then, due to bad management, damaging policies in industrial privatisation and huge accumulated debts, the factory faced a huge decline. Against such a backdrop, the sole opportunity to break the deadlock was privatisation. Through FPS (The State Ownership Fund) the factory privatised in 1996. Indeed, multiple interventions in the factory's recuperation were needed so as it could become integrally privatised in 2000. One year later, the state intervention in the factory's privatisation had been excluded. The private ownership led the plant to a massive decline. In 2001, the factory was fragmented and carved out. SC Rodex SA purchased the new section and the glass production was re-launched, but to a limited extent. The factory operated with approximately 100 workers. The work was unprofessional and performance levels were low. Thus, in 2003, the factory stopped operating. Furthermore, in its fragmented state, it was purchased by SC Lion Lanțuri SRL and SC Expert Ghinea Nicolae SRL. The new owners changed the profile of the factory and the glass production completely failed. In such circumstances, an old industrial tradition in glass production definitely ended. Due to the previous fragmentation since 2004, a PolishGerman Company that purchased a section of the factory bankrupted this manufacturer. In 2006, SC Magtomvic purchased what was left of the former factory and changed its profile to parquet production. Thus, an important part of the factory remained derelict and turned to ruins (Figure 3 upper left), while the front part of it was regenerated (Figure 5, lower left and lower right). The tensions between bad and good interventions of post-socialist privatisation in industry are highlighted by the presence of ruined and renewed parts (Figure 5, upper right). Besides the new investments in parquet production, an Italian Company purchased a small part of the factory for textiles production. Together with the frail post-socialist reindustrialisation, tertiarisation of the former industrial site came sooner than expected, with the appearance of commercial services. These shifts argue the processes of massive deindustrialisation, frail reindustrialisation and slow-go tertiarisation in rural areas. The issue of industrial ruins production because 
of the new post-90s capitalist order and economic changes (see Mah 2012; De Silvey and Edensor 2013; Edensor 2005a: 2005b) as well as the decreasing standards of rural living and rural deindustrialisation, are common features of most formerly industrialised Romanian villages and communes. Indeed, they also have important consequences for the local rural community.

Figure 5. The former glass factory between ruins and regeneration

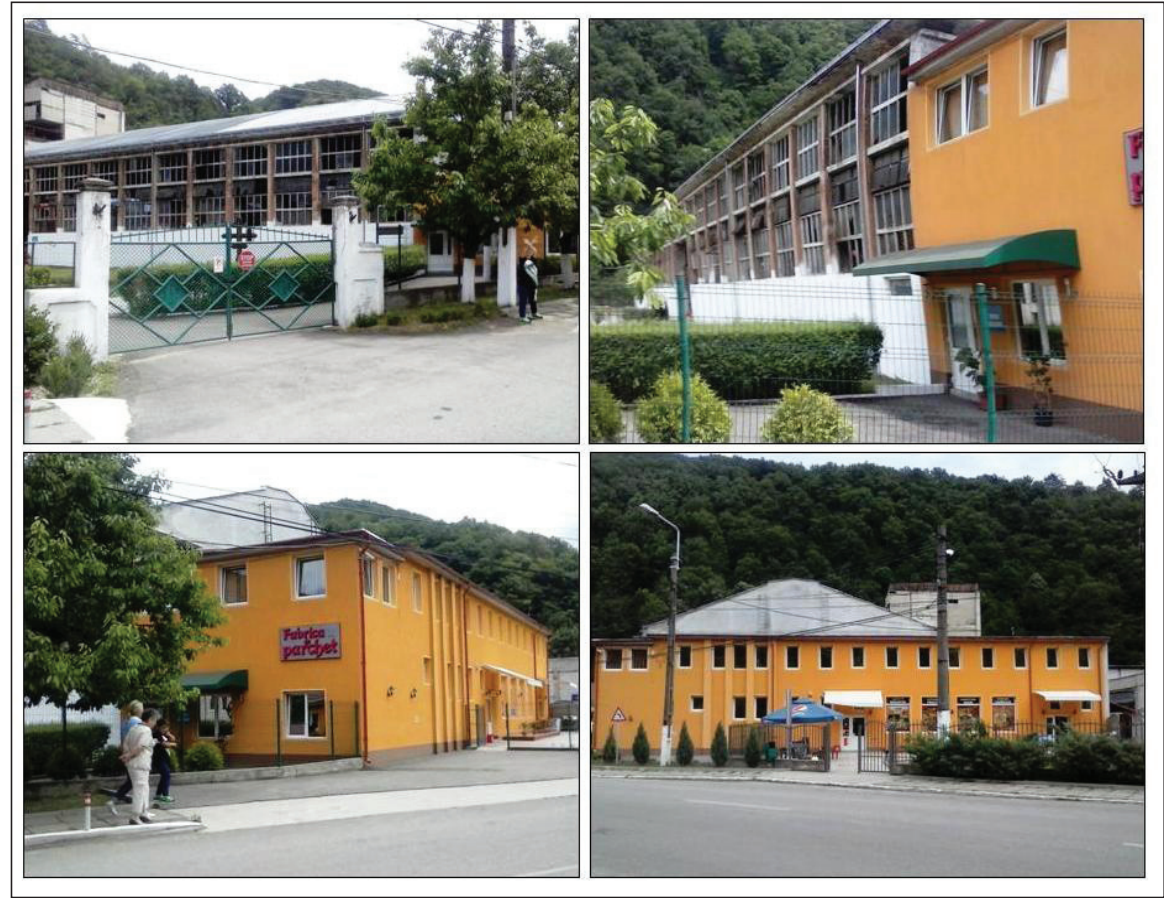

Source: photographs taken by author, 2015 .

Considering the failure of the former glass factory, the voices of the local community blamed bad interventions and mismanagement of the factory's privatisation. The post-socialist decline of the glass factory came with important negative consequences for the local rural community, both in the colony and in the Tomești comune. Privative upshots rapidly occurred in local employment, local welfare and in the local living standards of the residents. Following the former glass factory's termination of production, massive unemployment emerged in this local community. There were dramatic times for the Tomeşti Colony and the Tomeşti commune because 
of the national economic instability. After 2000, an important commutation process started, with the residents of Tomești, formerly employees in local industry, commuting to Făget and Lugoj for work; this was essential in order to ensure their modest incomes for daily living. The other part of the labour force remained occupied in the local subsistence agriculture and in the forestry sector. In time, the standards of the local residents decreased, regardless of whether these people were living in collective communist buildings in the colony or individual dwellings in the village. A former worker at the plant and resident in one of the state-socialist blocks of flats (Figure 6) of the colony stated:

'Our daily life is hard. It is a continuous fight for subsistence. We live in these minimalist blocks of flats with lower facilities. Thus, we lived under statesocialism as how we live now, excepting our incomes. Formerly we had money for our existence. Now many of the residents do not have any income. They work occasionally or offer daily services to sustain their daily life. We, as residents in these flats, have no land to cultivate some food and have no opportunities of animals growing. Furthermore, our living is improper with no centralised facilities (for instance gas, centralised TV signal, current centralised heating, or current heat water). We use wood heating and stoves ensuring these domestic supplies. See these large piles of wood on the ground floor of this collective building. In the century of civilisation, our living standards fall behind. These wood resources are used for ordinary heating of the apartments or for self-provisions for winter. Many of us procure the wood in summer because of its cheap price. There are cases when my neighbors brought the wood using rates because of their low incomes' (Personal conversation, Constantin/59/male).

Poverty and low living standards are the key words, both for the colony and for the Tomesti commune. Since it was not included in the local major development programmes, the decline of this settlement is obvious. It is not only applicable to the residents of the collective buildings, but also to those living in individual households. The main advantage of the latter is the presence of gardens in their households - an important resource in producing their food supplies. In these families, the husbands frequently work in factories located in the nearest towns, be it on a daily basis or occasionally where needed. Those formerly employed in the glass factory have lost the stability 
Figure 6. A collective state-socialist building in Tomesti Colony

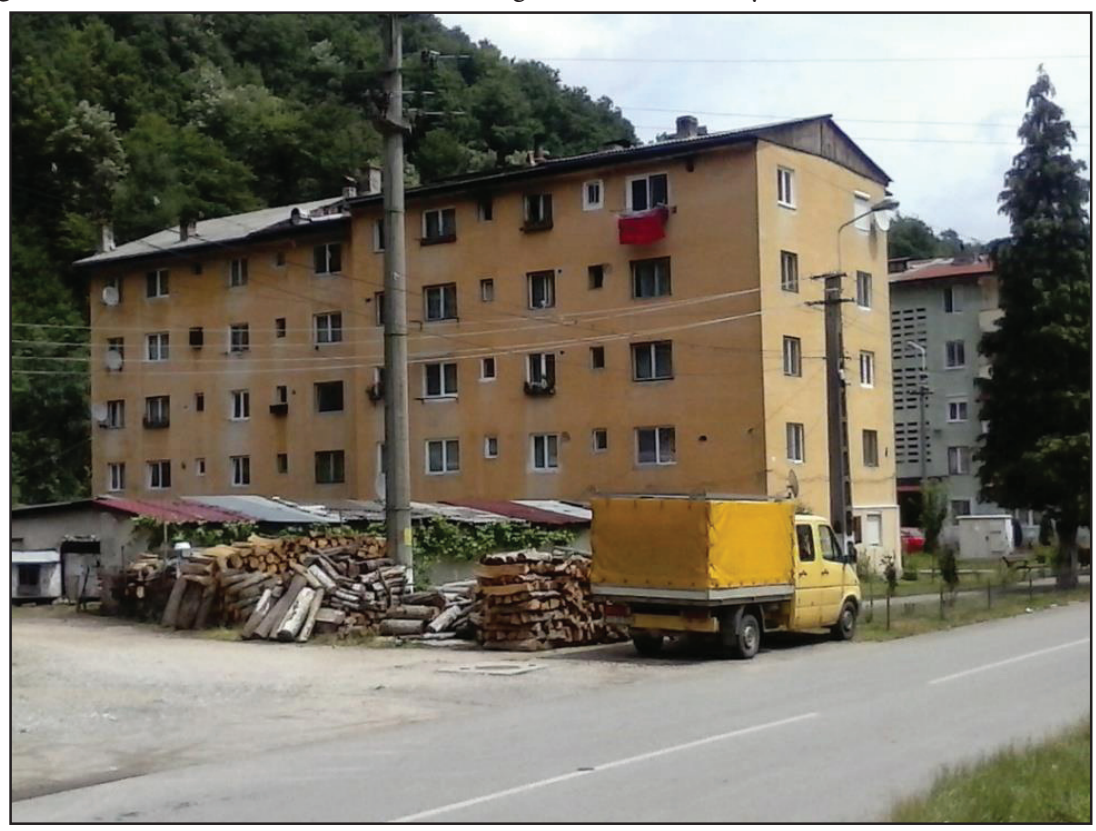

Source: photographs taken by author, 2015.

of their daily lives since the process of rural deindustrialisation started. Regretting the demise of what once was, a local resident claimed:

'Perhaps the Ceausescu's state-socialist industrialisation was not good, altering Romanian rural areas with artificial interventions in this village, but the post-socialist restructuring strongly altered this site as well. Whether then the people living here had a certain job and a safe income, now the local residents have a day-to-day living, facing with important social and economic problems. Look at these houses in the village (Figure 7). Most of them are modest or poor with no or low improvements, hosting old and poor people. As you can see, the authorities' interventions in local rural development are reduced, except the minor private investment. This area has a great natural and cultural touristic potential but who would exploit it in the beneficial of the local community?' (Oral history/Personal conversation, Dumitru, $61 /$ male). 
A glance at the housing stock of Tomesti village illustrates both the poor residences and dwellings (Figure 7, upper left and right) and the poor standard of living in a beautiful natural attractive landscape. Very few of these individual houses have been restored over the last decades, with the main interventions coming from their owners (Figure 7, lower left and right).

Figure 7. Pictures of rural housing in Tomesti Village

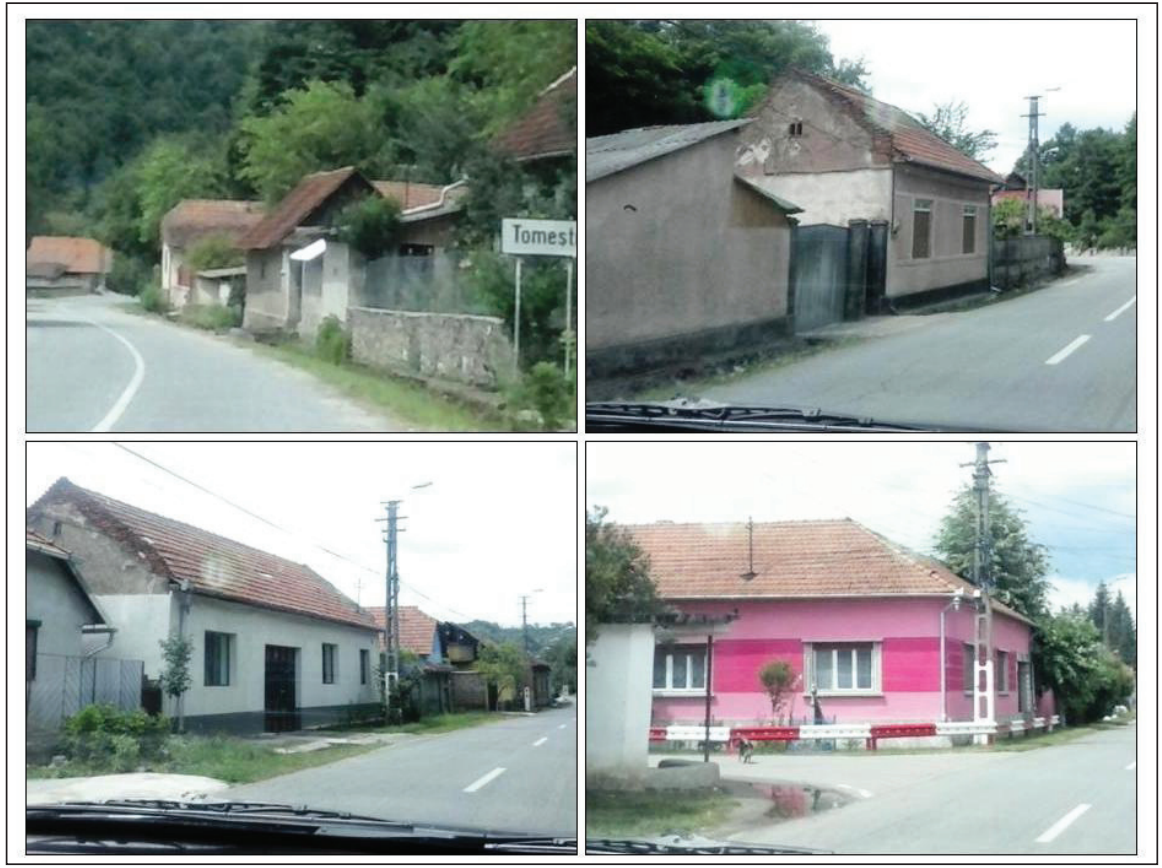

Source: photographs taken by author, 2015.

A review of the official documents of Tomesti village launched on the Timis County Council website reveals both the small interventions of the local authorities and the rural development projects with EU funds in the local rural development. Of these interventions and projects, the majority are still just proposals or ongoing projects focussed on the local roads, infrastructure improvement, the restoration of local cultural houses and other institutions, and the capitalisation of the local cultural and natural potential. However, these proposals have come 25 years after the state-socialism collapse against the backdrop of the local social and economic decline of this rural community. 
Despite the recent development of these projects, the issues of local social and economic welfare in rural regeneration remain peripheral. The current institutional collaboration of the local authorities with other local, regional and national institutions and organisations could be further capitalised to promote local rural development. The repeated infield observations in this investigated site along with the oral conversations conducted with locals and with oral histories of residents living in this village, allowed for the setting out of certain major interventions to regenerate this community.

Firstly, the inclusion of social and economic development programmes in the local agenda is essential. This is related to local resources, especially wood and raw materials. Accordingly, the availability of the local labour force represents a great opportunity for new investors. Consequently, the local promotion, encouragement and development of SME (Small and Medium Enterprises) would be a definitive form of action in local rural development. Secondly, the optimal capitalisation of the local cultural heritage and natural potential of this area could be properly used through the development of touristic services. In this regard, since local natural and anthropic potential provide significant opportunities, agritourism activities could be further developed, sustaining economic benefits for the local rural community (Srisomyong and Meyer 2015). Thirdly, and with regard to the touristic sector, the ruined site of the former glass factory could also be taken advantage of in the field of cultural and industrial tourism through the restoration of the former sections of glass production. Thus, the local cultural and industrial heritage grounded in the earliest Romanian capitalism would remind the current visitors in this rural area about the local cultural traditions and heritage. Fourthly, more major investments in the local social and economic field through EU funds, national implication and private-public interventions would represent favourable action in the further rural development of this commune. Consequently, a new agenda of local rural development is required to eliminate both the negative impacts of state-socialist industrialisation and those features brought about by post-socialist deindustrialisation and post90 s rural management ruled by the local authorities.

\section{Margina village and its industrial ruins}

An appropriate story at this point is that of the Margina commune. Hosting an important vinegar manufacturer during the state-socialist period, the village 
is now home only to ruins (Figure 8), thus exemplifying the incorrect processes of industrial privatisation in rural areas.

'Once upon a time, there was an important traditional and successful factory producing vinegar, with their products appreciated throughout Romania. Now all tradition collapsed and the people reminds the vinegar production only by these ruins bordering the national road. It is however purposely placed along the road for everyone who crosses the village to see the crimes of postsocialist privatisation in rural Romania. These ruins are ghosts of the present.' (Personal conversation, Nicolae, 69/male).

These are the words of an old man living across the street, opposite the ruined vinegar factory. His opinion is in line with Edensor's (2005a; 2005b) statements that industrial ruins are ghosts of the current dereliction and the post-90s capitalism. The story of this factory is similar to that of the previous glass factory Tomești. The railroad between Lugoj and Ilia was built at the end of the $19^{\text {th }}$ Century. It is an important railway linking the western and central parts of Romania, and it was constructed in order to attract important investors in this area. In 1910, Rozskatol Company from Budapest asked a German society to design a plan to build a new manufacturing facility for the chemical distillation of beech wood. The factory started operating in 1912 up until to the First World War. Its production was based on local wood resources. It was re-launched in 1921 with Romanian capital; up until 1930 the factory produced acetone and then vinegar and canned cucumbers and pickles. Production can be estimated at 20 trucks per season. Because of the transition to state-socialism during 1945 and 1947 it was closed, before being nationalised in 1948. Indeed, this was also the case for the glass factory from Tomeşti and for all private manufactures at that time. Since 1968, the factory, with its 600 employees, became a section of a huge petrochemical plant in Timişoara - C. P. Solventul ${ }^{3}$. The latter is now ruined and derelict, thus illustrating improper privatisation policies and interventions in local

3 The information concerning this manufacturer was provided by the local monographs (see for instance Matei 2007) and by the following valuable websites available at http://prinbanat. ro/a-fost-odata-o-fabrica-de-otet/ http://punctedefuga.ro/2011/09/fabrici-vechi-fabrica-dinmargina/ www.enciclopediaromaniei.ro/Margina_(Timis C5s9F).http://www.gazeta-de-vest. ro/tragedie-la-fosta-fabrica-de-otet-din-margina-un-barbat-si-riscat-viata-incer- candsa-fure-fier-vechi/.www.tion.ro/acoperis-prabusit-peste-doi-hoti-de-fier-vechi-la-marginao-persoana-a-murit-strivita/1496690.http://www.mediafax.ro/social/un-mort-si-un-ranit- 
industrial restructuring (see Voiculescu and Jucu 2014). In 1989, the year of the state-socialism collapse in Romania, the factory was in a real process of expansion and development, although its decline came sooner. It is argued that the factory was deliberately closed and sold as scrap. This had been a common practice across all of Romania since the commencement of industrial privatisation. The oral histories of the local residents blame the mismanagement on the Romanian privatisation (Kideckel, 2008) with no transparent procedures. The main objective of the factories' privatisation was self-enrichment of the post-socialist owners. In this regard, a former employee stated:

Figure 8. The ruins of the former Vinegar Factory in Margina

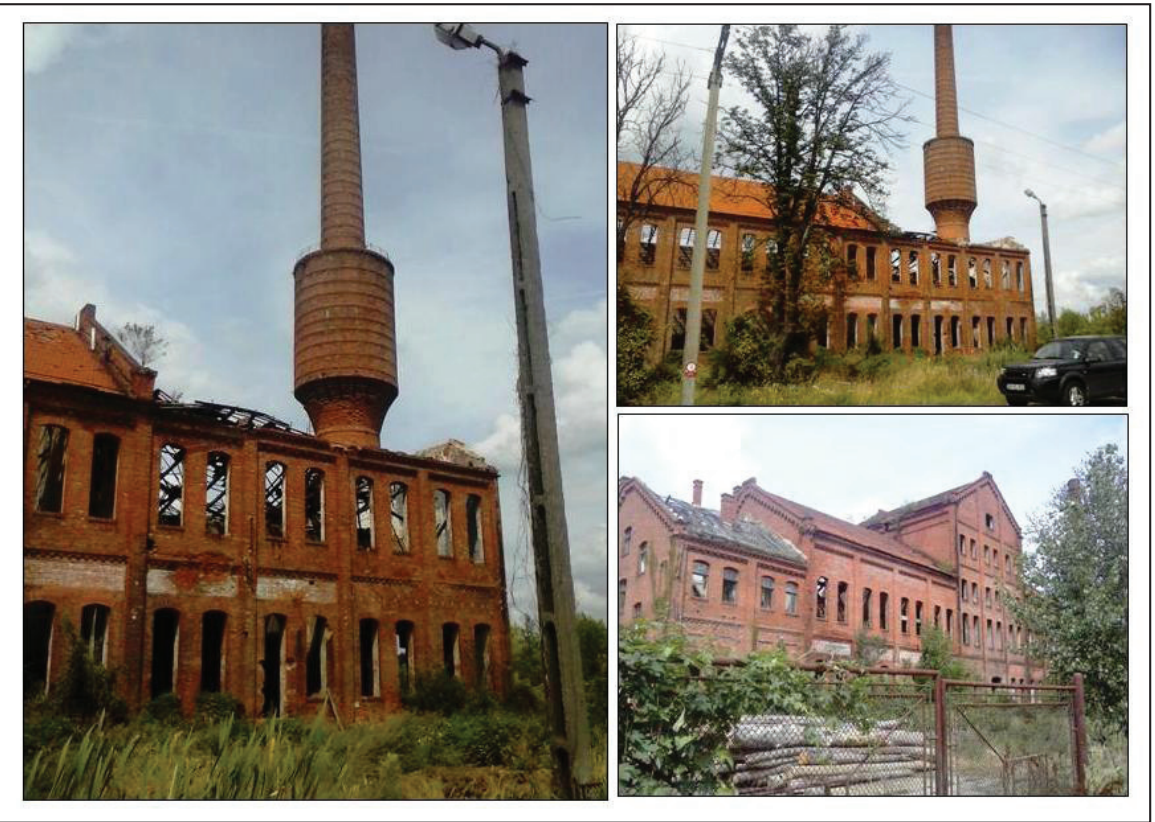

Source: photographs taken by author, 2015.

I used to work in this factory. It is hard to believe that it is ruined now. You cannot imagine how was here sometime. Full trains of workers and commuters came to work in this manufacturer together with local employees.

dupa-ce-plafonul-unei-fabrici-dezafec tate-din-timis-s-a-prabusit-peste-ei-13776151. www. prinbanat.ro, online accessed June-July, 2015. 
The commune was full of people and the vinegar's smell was all around, including in the trains. The vinegar of Margina was appreciated as well as the canned food. Since the factory closed down, we have witnessed its continuous degradation. From here was thieved everything by scavengers, including iron and steel bars, the glass of the windows and even the tiles and bricks made by Muschong - appreciated all around the Austro-Hungarian Empire. What was not stolen was destroyed. Look at that building. Look at the left side part of it. (Figure 9) A whole wall collapsed. Of this place, there were stolen everything: so-called new capitalist owners and even poor people scavenged and sold theft materials as scrap. It is a tragedy and now under post-socialism and the new rules of the market economy that would promise welfare the all-industrial tradition died. Moreover, do you know what is paradoxical? In the right part of this ruined factory is the headquarters of a new centre of local economic development. What they are doing? They're doing nothing. Unfortunately, the local authorities do nothing... ' (Personal conversation, Ioan, $72 /$ male).

The above statement triangulates Chelcea's theories (2015), which were demonstrated in his study on Romanian post-industrial ecologies, whereby marginal groups of people scavenge ruined sites following their collapse. While some interviewees highlighted the former success of this factory, other voices considered that the goods produced in the plant would become no more competitive in the post-socialist markets. In the face of present globalisation, it is more convenient to buy chemical vinegar produced abroad rather than to use the natural, bio vinegar.

'Now the vinegar is artificially produced using chemical and unhealthy elements. Why use the natural vinegar produced through fermentation when we could obtain vinegar using a single lozenge. Who cares about our health? Does our vinegar was no more good?' (Personal conversation, Domnica, $56 /$ female).

This latter question is, however, rhetorical. Of course, based on proper management of post-socialist Romanian economic restructuring, many national traditional brands could survive. Other interviewees blamed the incorrect privatisation of the Romanian industry. In this regard, a local resident stated: 
'Before that everything was stolen, once that Romanian deindustrialisation began with factories turned to ruins, this process strongly damaged the local way of life in rural communities. Whether under state-socialist period the people from Margina had a job, this feature is no more available during the post-90 times. Many residents work in local agriculture to maintain their daily subsistence. Other people commute to towns such as Lugoj and Făget to work in the industrial sector. Many of local teenagers moved out for a better life in urban areas or abroad. This village is in decline. This is obvious both in the local way of life of the rural inhabitants and in the village landscape. Look around, these collective houses of the former industrial colony are completely damaged. Their tenants living in poor apartments face with hard livingconditions and poverty. Even though many blame the state-socialist period I think that those times were better. Since then, we lost our welfare, our industry and the local cultural traditions. The vinegar factory was emblematic for this community as it was for the western part of Romania. Now, look around: ruins that stand to fall surrounded by weeds, damaged houses, poverty and ignorance' (Interviewee, Marin/62/male).

In addition to these negative features, a new issue emerged during oral communication with interviewed residents: the risk for the local community. The industrial ruined sites, with their abandoned and shattered buildings standing to fall, represent a real risk for the local community. There was a time when people would die as they searched for scrap ${ }^{4}$. In line with these events, the local residents confirmed that this issue was revealed by local and national media. For instance, a rural resident stated:

4 According to: Iosa, G., 2015. 'A murit încercând să fure fier vechi. Tragedie la fabrica de oțet din Margina' ['Dead in the attempt to steel scrap. Tragedy at the Vinegar factory from Margina'], Redeşteptarea, 20 of January 2015 See also the following websites: http:// redesteptarea.ro/a-murit-incercand-sa-fure-fier-vechi-tragedie-la-fabrica-de-otet-dinmargina_18305.html; accessed 12.06.2015; ${ }^{\star * *}, 2915$. 'Acoperiş prăbusit peste doi hoți de fier vechi, la Margina. O persoană a murit strivită ['Roof crashed on two scrap thieves at Margine. A person died'], 20 of January, 2015, timiş online available at http://www.tion.ro/acoperis-prabusit-peste-doi-hotide-fier-vechi-la-margina-o-persoana-a-murit-strivita/1496690;2015, See also other media sources on this topic available at: http://www.ziare.com/stiri-timisoara/stiri-actualitate/a-muritincercand-sa-fure-fier-vechi-tragedie-la-fabrica-de-otet-din-margina-5255626; http://www. romaniatv.net/un-barbat-a-murit-altul-e-grav-ranit-dupa-ce-acoperisul-unei-cladiri-aflatein-paragina-s-a-prabusit_196714.html, accessed online 12 of June, 2015. 
'This ruined site of the former vinegar factory is completely unsafe. In addition to the local defacement generated by these ruins, they harm the community safety. Recently, thieves that came here to steal scrap were seriously affected. It is known that a person lost his life. It is clear that these ruins are a serious danger for everyone' (Interviewee, 54/male).

Considering the present and further interventions of local authorities, the problems remain complicated. With the ruins now standing as proof of the post-socialist Romanian rural deindustrialisation, their presence in rural areas, 25 years after the state-socialism collapse, illustrates the authorities' indifference. This general statement, which was translated from ubiquitous sites in Romanian urban and rural areas, fits with the Margina case (see Figure 9), and thus is harmful to local welfare and the rural landscape.

Figure 9. Different aspects of the ruined site of the former vinegar factory.
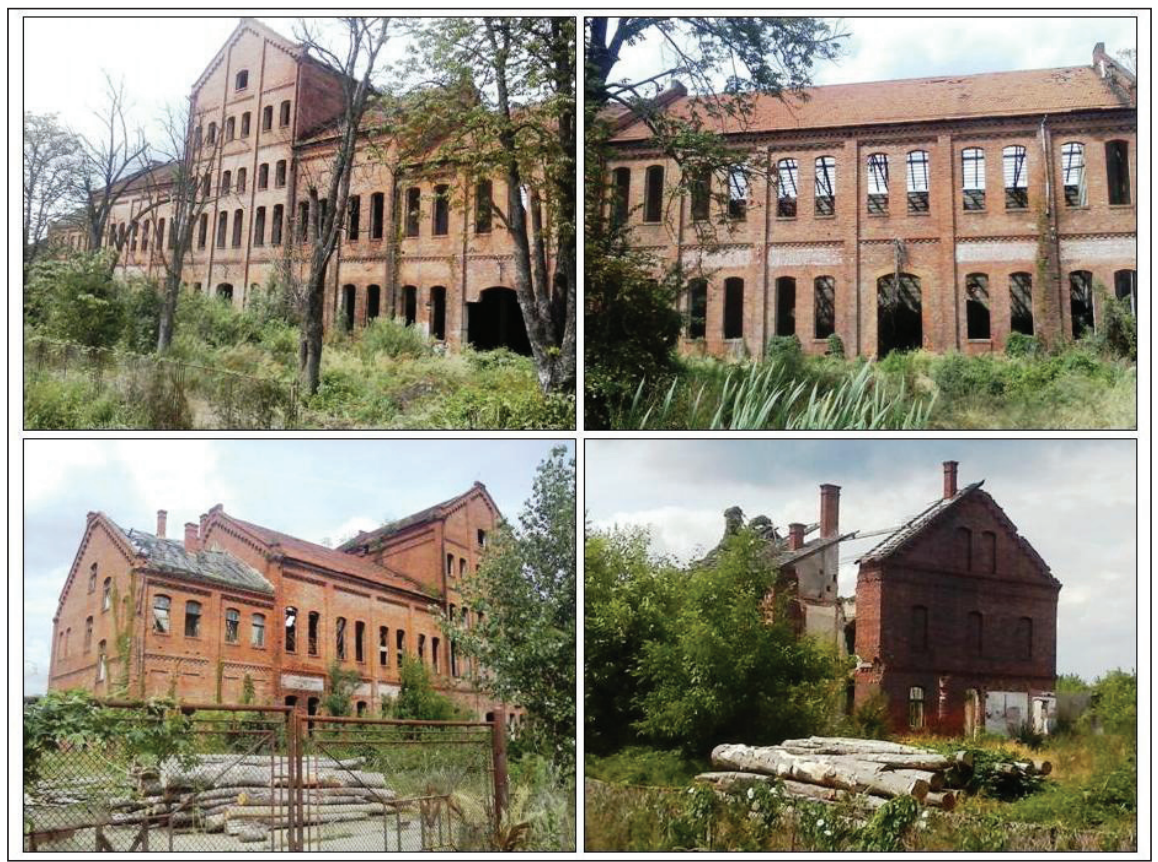

Source: photographs taken by author, 2015.

In addition, many policies related to urban and rural regeneration were slow in producing results; indeed, they were rather theoretic without 
providing any direct spatial implication. Consequently, between theory and practice, these policies must be immediately and practically designed before being applied to the local, regional and national scale of Romanian rural development, against the backdrop of post-socialist rural identity formation.

\section{Conclusions}

This article discussed the major rural transformations in rural areas, with special consideration given to two major interventions ruled by different Romanian political systems: the formerly state-socialist industrialisation led by Romanian Communist-Party Rule, and the post-socialist economic restructuring in rural areas through the lens of local deindustrialisation. These different processes, with their direct implications for the welfare of these rural communities, were based on the historical background of Romania's earlier capitalism, when the first traditional manufacturers appeared. They designed the primary industrial profile of these rural areas upon which the state-socialist regime artificially expanded rural industrial activities to a large extent. They came with major transformations in the investigated rural areas through industrial colonies and an egalitarian way of life for the local residents. Furthermore, the state-socialist industrialisation altered the former rural profiles, with the industrial sector aiming to turn the rural sites into urban settlements over time. This was the destiny of many formerly Romanian rural settlements. The year of 1989, which saw the collapse of the former state-socialist regime, would have to determine new changes in the Romanian countryside.

With regard to the investigated communes of Tomești and Margina, the post-socialist economic restructuring in rural areas, through deindustrialisation, led to bankruptcy of the state-socialist manufacturers, which then turned into ruined areas and derelict rural places. In addition, a major decline in the living standards of the rural residents occurred, both in the rural colonies and in the communes and their associated villages. The local rural ruins are evidence in favour of the argument that deindustrialisation turned state-socialist rural industry into real ghosts of current capitalism (see Edensor, 2005a, 2005b) and globalisation. In other words, the current trends of globalisation alter local cultural tradition. The new frail economic investments and government interventions in rural 
development have not been able to swing the loss of the post-socialist period. The local residents of these rural areas face multiple consequences of transition and of the new rules of the capitalist economy in rural areas. Poverty, reduced standards of living, difficult day-to-day life, unemployment, job insecurity and low incomes are the major problems that these local rural communities face. The rural regeneration actions of the local authorities failed to eradicate the negative impact of post-socialist deindustrialisation. Furthermore, new post-socialist institutions with competencies in rural local development illuminate minor implications in solving the problems which have occurred since the start of rural deindustrialisation.

The development programmes in rural investigated sites are at a slowgo pace, remaining mainly as proposals and theoretical backgrounds rather than constructive practices in post-socialist rural identity formation. Furthermore, the local rural traditions are lost, with important implications for the Romanian rural culture. Against such a backdrop, new actions in redefining the local agendas on rural development are required. They had to set together the voices of the local stakeholders, local residents, local governors and scientists of different backgrounds, to design new optimal directions in rural development of the former Romanian industrial countryside.

\section{Acknowledgements}

The author expresses his grateful thanks to the Eastern European Countryside Journal editors for their valuable criticism; he also extends his acknowledgement to the two anonymous reviewers' comments on the earlier version of the paper. Indeed, these comments were helpful in improving the content of the article. The contribution was conducted within the Strategic Grant POSDRU/159/1.5/S/133391 with a Research project entitled Neoliberalism and the Romanian post-socialist cities' responses to the present development policies on urban restructuring in Timis County of Romania. 


\section{References}

Artemov, V. \& Novokhatskaya, O., 2014. 'Everyday activity of rural employees in Siberia', Eastern European Countryside, Vol. 20, pp. 189-210. Available at: http://dx.doi.org/10.2478/eec-2014-0009

Arunas, J. \& Arunas, P., 2010. 'Conceptualising the rise of the rural community movement in Lithuania: A framework for analysis', East European Countryside, Vol. 16, pp. 65-88. Available at:

http://dx.doi.org/10.2478/v10130-010-0004-6

Bečicova, I. \& Blažek, J., 2015. 'Is there a credit-gap in a periphery? The perception of this problem by small entrepreneurs', Journal of Rural Studies, Vol. 42, pp. 11-30. Available at: http://dx.doi.org/10.1016\%2Fj.jrurstud.2015.09.006

Baum, S., 2011. 'The tourist potential of rural areas in Poland', East European Countryside, Vol. 17, pp. 108-135. Available at:

http://dx.doi.org/10.2478/v10130-011-0006-z

Bradea, M., Marin, I., Morodan, I., Minda, L. \& Bălan, R., (eds.) 1981. Timiş. Monografie [Timis Monograph], Bucharest: Ed. Sport Turism.

Bucher, S. \& Nováková, S., 2015. 'Territorial aspects of regional identity and respondents' identification with the region and place: case study of Slovakia, Eastern European Countryside, Vol. 21, pp. 81-109. Available at:

http://dx.doi.org/10.1515/eec-2015-0005

Ceaușescu, N. \& Ceauşescu, M., 2004a. Monografia comunei Margina, Vol. 3 - 225 de ani de învățământ românesc stimă dascălilor de ieri şi de azi [Monograph of Margina Commune, Vol 3, 225 Years of Romanian education, honor to the teachers from now and yesterday], Lugoj: Nagard.

Ceaușescu, N. \& Ceauşescu, M., 2004b. ,Monografia comunei Margina, Vol. 4 - Viața spirituală şi sfintele biserici [Monograph of Margina Commune, Vol. 4, The cultural life and local churches], Lugoj: Nagard.

Ceaușescu, N. \& Ceauşescu, M., 2006a. Monografia comunei Margina, Vol. 1 - Spațiul geografic şi etnografic [Monograph of Margina Commune, Vol. 1, The geographic and ethnographic space], Lugoj: Nagard.

Ceaușescu, N. \& Ceauşescu, M., 2006b. Monografia comunei Margina, Vol. 2 - Un colț de țară: o pagină din istoria națională [Monograph of Margina Commune, Vol. 2, A part of the country a page of the national history], Lugoj: Nagard.

Chelcea, L., 2008. Bucurestiul postindustrial. Memorie, dezindustrializare si regenerare urbana [The Post-industrial Bucharest. Memory, deindustrialization and urban regeneration]. Bucharest: Polirom.

Chelcea, L., 2012. 'The 'Housing Question' and the State-Socialist Answer: City, Class and State Remaking in 1950s Bucharest'. International Journal of Urban and Regional Research, Vol. 36 No. 2, pp. 281-296. Available at: http://onlinelibrary. wiley.com/doi/10.1111/j.1468-2427.2011.01049.x/abstract 
Chelcea, L., 2015. 'Postindustrial Ecologies: Industrial Rubble, Nature and the Limits of Representation'. Parcours Anthropologique, Vol. 10, pp. 186-201. Available at: http://pa.revues.org/448

Čikić, J. \& Petrović, M., 2015. 'Rural families and households in post/socialist transition. Serbian experience', Eastern European Countryside, Vol. 21, pp. 35-62. Available at: http://dx.doi.org/10.1515/eec-2015-0003

Clark, A. N., 1998. Dictionary of Geography, London: Penguin.

Cloke, P. \& Little, J. (eds.), 1997. Contested cultures: otherness, marginalization and rurality. London: Routledge

Cloke, P., 2014. 'Rurality', in: P. Cloke, P. Grang \& M. Goodwin (eds.) Introducing human geographies, Third Edition. Abingdon \& New York: Routledge, pp. 720737.

Cloke, P., Crang, P. \& Goodwin, M. (eds.), 2014. Introducing human geographies, Third Edition. Abingdon \& New York: Routledge.

Cloke, P., 2014. Rurality, in: P. Cloke, P. Grang \& M. Goodwin (eds.) Introducing human geographies, Third Edition. Abingdon \& New York: Routledge.

Crețan, R., 2006. Etnie, confesiune și comportament electoral în Banat [Ethnicity, religious confessions and electoral behaviour in Banat], Timișoara: Ed. Universității de Vest, Timișoara.

DeSilvey, C. \& Edensor, T., 2013. 'Reckoning with ruins', Progress in Human Geography, Vol. 37 No. 4, pp. 465-485. Available at: http://dx.doi.org/ 10.1177/ 0309132512462271 http://phg.sagepub.com/content/37/4/465.full.pdf+html

Edensor, T., 2005a. Industrial ruins. Space, aesthetics and materiality. Berg: Oxford.

Edensor, T., 2005b. 'The ghosts of industrial ruins: Ordering and disordering memory in excessive space', Environment and Planning D: Society and Space, Vol. 23 No. 6, pp. 829-849. Available at: http://dx.doi.org/10.1068/d58j.

Esparcia, J., Escribano, J. \& Serrano, J. J., 2015. 'From development to power relations and territorial governance. Increasing the leadership role of LEADER local action groups in Spain', Journal of Rural Studies, Vol. 42, pp. 29-42. Available at:

http://dx.doi.org/10.1016/j.jrurstud.2015.09.005

Ghinea, E. \& Ghinea, D., 2000. Localitățile din România [Localities of Romania], Bucharest: Ed. Enciclopedică.

Ghinea, D., 2000. Enciclopedia Geografica a Romaniei [The Geographic Encyclopedia of Romania], Bucharest: Ed. Enciclopedică.

Gorlach, K., Klekotko, M. \& Nowak, P., 2014. 'Culture and Rural Development: Voices from Poland', East European Countryside, Vol. 20, pp. 6-26. Available at: http://dx.doi.org/10.2478/eec-2014-0001

Hedlund, M. \& Lundholm, E., 2015. 'Restructuring of rural Sweeden Employment transition and out-migration of three cohorts born 1945-1980', Journal of Rural Studies, Vol. 42, pp. 123-132. Available at: http://dx.doi.org/10.1016/j. jrurstud.2015.10.006 
H. G. 1245, 1990. Government Decision 1245, Romanian Parliament, Bucharest: Romania.

Ianoş, I., 2005. Geografie urbană și rurală [Urban and rural Geography], Bucharest: MEdC.

Iosa, G., 2015. 'A murit încercând să fure fier vechi. Tragedie la fabrica de oțet din Margina' ['Dead in the attempt to steel scrap. Tragedy at the vinegar factory from Margina'], Redeşteptarea, January, 2015, Lugoj. Available at: http: www. redesteptarea.ro.

Jakimovski, J., 2010. 'The socio-demographic context of rural poverty', East European Countryside, Vol. 16, pp. 131-155. Available at: http://dx.doi.org/10.2478/v10130010-0007-3

Jucu, I. S., 2011. Analiza procesului de restructurare urbana in municipiul Lugoj [The analysis of the process of urban restructuring in the Municipality of Lugoj], Timisoara: West University of Timisoara Publishing House.

Jucu, I. S., 2015. 'The post-socialist urban restructuring at the local scale. Evidence of simultaneous process of de-/reindustrialization in the Lugoj municipality of Romania. Journal of Balkan and Near Eastern Studies, Vol. 17 No. 4, pp. 408426, Available at: doi: 10.1080/19448953.2015.1063302

Kaplan, D., Wheeler, O. J. \& Holloway, S., 2009. Urban Geography, Second Edition, London and New York: Wiley.

Kerekes, K. \& Pakucs, B., (2013), 'Occupational Choices of Romanian Rural Youth', East European Countryside, Vol. 19, pp. 57-76. Available at: http://dx.doi. org/10.2478/eec-2013-0004

Kideckel, D. 2008. Getting by post-socialist Romania: labor, the body and working-class culture, Bloomington: Indiana University Press.

Kiss, E., 2007. 'The evolution of industrial areas in Budapest after 1989', in: K. Stanilov (ed.) The post-socialist city: urban form and space transformations in Central and Eastern Europe after socialism, Springer, Dordrecht, pp. 147-172.

Kovács, K. 2010. 'Social and Administrative Crises Interlocking: The Misery of Rural Peripheries in Hungary', Eastern European Countryside, Vol. 16, pp. 89-113. Available at: http://dx.doi.org/10.2478/v10130-010-0005-5

Law, No. 15, 1990. Romanian Parliament, Bucharest: Romania.

Law, No. 31, 1990. Romanian Parliament, Bucharest: Romania.

Lukić, T., Penjišević, I., Đerčan, B., Đurđev, B. Živković, M. B. \& Armenski, T., 2014. 'Politics in the Balkan countryside', Eastern European Countryside, Vol. 20, pp. 99124. Available at: http://dx.doi.org/10.2478/eec-2014-0005

Mah, A., 2012. Industrial ruination, community and place landscapes and legacies of urban decline, Toronto: University of Toronto Press.

Manea, G., Matei, E., Vijulie, I., Marin, M., Cocos, O. \& Tiscovschi, A., 2013. 'Tradition and Modernity in the Romanian Rural Space. Case Study: the Arges 
Sub-Carpathian Foothills', Eastern European Countryside, Vol. 19, pp. 127-151. Available at: http://dx.doi.org/10.2478/eec-2013-0007

Matei, M., (ed.) 2007. Monografia comunei Tomeşti [The Monograph of Tomeşti Commune], Lugoj: Nagard.

Măjerová, V., 2009. 'Local Initiatives Functioning as a Condition of Rural Development of the Czech Countryside', Eastern European Countryside, Vol. 15, pp. 127-149. Available at: http://dx.doi.org/10.2478/v10130-009-0008-2.

McKee, A. J., 2015. 'Legitimizing the Liard? Communicative action and the role of private landowner and community engagement in rural sustainability', Journal of Rural Studies, Vol. 41, pp. 23-36. Available at: http://dx.doi.org/10.1016/j. jrurstud.2015.07.003.

Munteanu, I. \& Munteanu, R., 1998. Timiş. Monografie [The Monograph of Timiş County], Timişoara: Marineasa.

Mihalache, D. \& Nini, V., (eds.) 1971. Localitățile județului Timiș [The localities of Timiş County], Timișoara: CPJ Timis.

N. I. S., 2013. National Institute of Statistics. Tempo Online Databasis, Bucharest, Romania. Available at INSEE, www.tempoonline.ro.

Norton, W., 2004. Human Geography, London and New York: Oxford.

O’Brien, D., Españo, E., Grigsby, M. \& Patsiorkovsky, V., 2011. 'Entrepreneurial Attitudes in a Post-Communist Transitional Rural Economy: The Case of Moldova', Eastern European Countryside. Vol. 17, pp. 73-86. Available at: http://dx.doi. org/10.2478/v10130-011-0004-1

Pacione, M., 2009. Urban Geography. A global perspective, London and New York: Routledge.

Paddison, R. \& Hutton, T., (eds.) 2015. Cities and economic change. Restructuring and dislocation in the global metropolis, Los Angeles: Sage.

Preda, M., Vijulie, I., Manea, G. \& Mareci, A., 2015. 'The customary identity of the Coopersmiths Clan in Oltenia. Between tradition and Modernity', Eastern European Countryside, Vol. 21, pp. 63-80. Available at: http://dx.doi.org/10.1515/ eec-2015-0004.

Rey, V., Groza, O., Ianoş, I. \& Pătroescu, M., 2005. Atlasul României [Atlas of Romania], Bucharest: Rao Publishing Group.

Róbert, T. \& Levente, A. B., 2014. 'Appearance of European employment policy in the rural areas of Hungarian-Croatian border region case study in Serbia, Eastern European Countryside, Vol. 20, pp. 55-71. Available at: http://dx.doi.org/10.2478/ eec-2014-0003.

Stanilov, K., (ed) 2007. The post-socialist city: urban form and space transformations in central and eastern Europe after socialism, Dordrecht: Springer,

Srisomyong, N. \& Meyer, D., (2015), 'Political economy of agritourism initiatives in Thailand', Journal of Rural Studies, Vol. 41, pp. 95-108. Available at: http:// dx.doi.org/10.1016/j.jrurstud.2015.07.007. 
Șandru, I. \& Aur, N., 2009. Geografia așezărilor rurale [The Geography of rural settlements], Bucharest: CD Press.

Voiculescu, S., 2004. Orasele din Campia de Vest. Structuri si functionalitati urbane [The cities of Western Plain of Romania. Urban structures and functionalities], Timișoara: Ed. Universității de Vest, Timișoara.

Voiculescu, S. \& Jucu, I. S., 2014. 'Producing urban industrial derelict places: The Case of the Solventul petrochemical plant in Timişoara', European Urban and Regional Studies. Available at: doi:0969776414541134. 